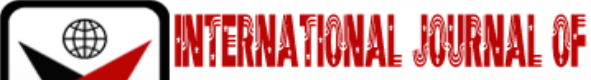

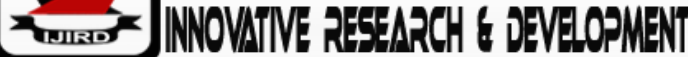

ISSN 2278-0211 (Online)

\section{Election Assessment in Dekina Local Government Area of Kogi State Using Geographic Information System Based Approach}

Salifu Joshua Ojotule
Assistant Lecturer, Department of Surveying \& Geoinformatics,
Federal Polytechnic Idah, Kogi State, Nigeria
Ojiako Johnbosco Chibueze
Professor, Department of Surveying and Geoinformatics,
Nnamdi Azikiwe University Awka, Anambra State, Nigeria
Duru Uchenna Uchechuku
Senior Lecturer, Department of Surveying and Geoinformatics,
Federal University of Technology Owerri, Imo State, Nigeria

\begin{abstract}
:
Geographic Information System based Approach to electoral mapping is an efficient platform that provides database useful for electoral officials to conduct elections, manage and analyze electoral dynamics. Dekina Local Government Area of Kogi State has recorded successions of election violence in some specific locations which has led to cancellation of election result in those areas, with challenges ranging from ballot stuffing, manipulation of result sheets, illegal creation of result sheet and a host of others. This study is aimed at using geographic information-based approach to monitor elections in Dekina Local Government Area of Kogi State. The objectives include; to digitize the required existing map of the study area, to generate thematic datasets needed for the study, to create a robust electoral database and conduct spatial and attribute queries that will show the potential of GIS in election monitoring within Dekina Local Government Area of Kogi State. The methodology employed in this study involved the conversion of analogue map to digital map which also involved the process of scanning, georeferencing, digitizing, geodatabase creation and query generation. The result obtained are the depiction of the spatial location of polling units within the study area, query result showing polling units with voter population above 500, 1000 and 2000 respectively, the depiction of polling units with records of violence that led to the cancellation of election result in the 2019 Presidential/House of Assemblies election. The study was able to find out that there are no polling units around Ochigi, Olaji at Ojikpalada ward in Dekina LGA. It was also able to find out that, just $20 \%$ of the entire population of Anyigba occupants is registered voters. This study was able to recommend that more polling units should be created at Ochigi, Olaji at Ojikpalada ward and also, more voter education and sensitization be carried out at Anyigba to increase voter population and create election awareness.
\end{abstract}

Keywords: Geographic information system, election, geo database

\section{Introduction}

Election involves the participation of the people in the act of choosing their leaders and their participation in governance (Waldemar, 2013). Election does not only consist of the activities that surroundelection day though it is part of the fundamental component, it encompasses activities even before, during and after elections. The use of GIS in elections can cover the whole elections cycle from boundary demarcations (polling units area mapping) to the stage of election result broadcast including results management and citizen participation (Ojiakoet al, 2016).

GIS has been discovered as one of the best techniques of the depiction of spatial data which has to do with the location of polling unit, the production of a robust database i.e., electoral database for the easy coordination, management and monitoring of elections and also the enhancement of geographic visualization of electoral dynamics and electoral demography. Also, GIS can help in the analysis of election violence i.e., knowing polling units that have record of violence. GIS have been identified as one of the $21^{\text {st }}$ century tools for communications, information processing and research enhancing abilities in findings, evaluation, integration, creating and analyzing issues and information at different levels (Omolekeet al, 2017).It has been discovered that there is a strong need of geospatial technology in the management of elections. This is because; violence in the elections is alarming due to the integrity of the country's electoral process that is at stake. Hence there is need to foster credibility and acceptable elections in Nigeria (Nwanegbo, 2015).

Electoral data and analysis involve a GIS based approach which can enable all voters and election officers to visualize relationship, patterns and trends to deeply understand their constituency and effectively manage the entire 
electoral process. GIS has been seen to provide accessibility of information with respect to all facets of electoral management cycle like voter registration, polling stations locator and election data on demand.

\section{Study Area}

Dekina is a local government area in Kogi State Nigeria (see Figure 1.1), located between Latitude 7을 $7^{\prime} \mathrm{N}$ and $7^{\circ} \underline{\mathrm{o}}$ $31^{\prime}$ North of the equator; Longitude 7 ${ }^{\circ} 09^{\prime} \mathrm{E}$ and $7^{\circ} 12$ East of the Greenwich meridian with estimated population of 260,968 (NPC, 2006) and an area of $2461 \mathrm{~km}^{2}$ (950sq miles).

\section{Methods}

The methodology adopted in this research which involves the data requirement, the data source, the data processing, techniques and approaches are presented in the list of subsections below

\subsection{Data Requirement/ Acquisition}

The data obtained for this study includes:

- The administrative maps of Nigeria, Kogi State and Dekina LGA was acquired for this project

- Road data of Dekina LGA was gotten from the digitizing of analogue map collected from ministry of Lands and survey. And ArcGIS online server was used to update the road data of the study Area.

- Polling unit Directory and Register for Dekina Local Government was sourced from the Independent National Electoral Commission (INEC) Kogi State.

- Total number of registered voters in the different polling units. This was extracted from the polling Register collected from INEC office.

- Location of polling units, security posts in Dekina Local government was collected using the Handheld GPS for depicting their spatial locations.

- Incidence of Election violence data of 2019 General and House of Assemblies Election was collected from INEC, also by Oral interviews and Newspaper publications

- Demographic data was sourced from the National Population Commission, Kogi State. Other relevant data was sourced from statutory bodies where necessary.

\subsection{Acquisition of Primary Datasets}

The primary datasets that were used for this research work were obtained through field visits; these includes:

- Positions or locations of polling units in Dekina Local Government was collected using a Handheld GPS.

- Attribute data: This includes non spatial descriptive information of the location of polling unit. E.g., polling unit location description

\subsection{Acquisition of Secondary Datasets}

The secondary datasets were gotten from digitization of available map data and attribute data such as:

- The administrative maps of Nigeria, Kogi State and Dekina Local government Area. These were sourced from from Ministry of Lands and Survey, Lokoja, also downloaded as a shapefile from google. Road data was gotten from the digitizing of analogue map which was collected from ministry of Lands and survey. Google image of the study was used to update the road map.

- Polling unit Directory for Dekina Local Government, was sourced from the Independent National Electoral Commission (INEC) Kogi State.

- Total number of registered voters in the different polling units were extracted from the Polling register to be collected from INEC office.

- Incidence of election violence data was collected from INEC, police stations and other social handles

- Demographic data was sourced from the National Population Commission, Kogi State.

\subsection{Data Processing}

The methodology that was employed in this research involves conversion of analogue map into digital map, updating of Dekina street map using the ArcGIS server, plotting of coordinate points of polling units and nearby police stations, Geo-database creation and queries generations. First, the analogue map of Dekina Local Government was converted to digital through the process of scanning, georeferencing and digitizing. Subsequently the street map was updated using ArcGIS server in the ArcMAP 10.5 environment, georeferencing and digitizing was done using ArcGIS 10.5 environment. The coordinate points of polling units were plotted on the map, after which a robust geospatial database was created with the demographic and voter information. Consequently, the database was analysed and various queries were generated.

\subsection{Data Modelling in GIS}

A data model is a set of constructs for describing and representing selected aspects of the real world in a computer (Batty et al, 1999). According to Longley (2001), when representing the real world in computer, it is helpful to think in terms of four different levels of abstraction. First, reality is made up of real-world phenomena, and includes all aspects that may not be perceived by individuals, or deemed relevant to particular application. Second, the conceptual model is a human oriented, often partially structured, model of selected objects and processes that are thought relevant to a 
particular problem domain. Third, the logical model is an implementation-oriented representation of reality that is often expressed in the form of diagrams and lists. Forth, the physical model portrays the actual application in a GIS, and often comprises tables stored as files or databases.

There are three important components of geographic data (Spencer, 2001):

- The spatial data: Geographic position specifies the location of a feature or phenomenon by using a coordinate system, which are used for representing geographical places: wards, towns, polling units, schools.

- The attribute data: Attribute data refer to the properties of spatial entities, which describe the characteristics of the geographic features: population, length, and area. Spatial features in a GIS database are stored in either vector or raster form.

- Vector data: GIS data structure adhering to a vector format store the position of map features as pairs X, Y (and sometimes Z) coordinates. A point is described by a single X-Y coordinate pair and by its name or label. A line is described by a set of coordinate pairs and by its name or label. Therefore, a line is built up of straight-line segments. An area, also called polygon, is described by a set of coordinate pair and by its name or label with the difference that the coordinate pairs at the beginning and end are the same. A vector format represents the location and shape of features and boundaries precisely. Only the accuracy and scale of the map compilation process, the resolution of input devices and the skill of the data-in putter limit precision.

\subsection{Database Design}

Database design is the process of producing a detailed data model of a database (Harnandez, 2012). It consists of three design phases (Kufoniyi, 1998)

- Conceptual Design

- Logical Design

- $\quad$ Physical Design

The conceptual Design is the first stage that deals with the identification and description of the contents to be embedded in the database and this is done independently of the software and hardware that will be used to implement the database.

Logical Design is another stage of the database design where real world entities conceptualized are modeled into the real world. It is usually the representation of the conceptual design to reflect the recording or inputting of the data into a computer system using the relational database management system.

Physical Design is the stage that involves the interpretation of the real-world entities into the computer compactible forms of the chosen model which may be relational hierarchical for ease of implementation and management. Information stored in the database allows for easy access, retrieval, update and also provides ease for performing analytical functions that can supply information from the installed database.

\section{Results and Discussion}

The result obtained from this study include statistical analysis of the spatial spread of voters, updated Dekina local Government Area road map showing the spatial distribution of polling units and various queries conducted on the geospatial database.

\subsection{Population and Voter Spread within Dekina LGA}

Inec voter register shows that, Dekina LGA has a total voter population of about 166,165 people. This number is distributed among the wards that make up the Local Government Area.

\begin{tabular}{|c|c|c|c|}
\hline S/N & Wards & Voter Population & Percentage \% \\
\hline 1 & Dekina Town & 12589 & 7 \\
\hline 2 & Iyale & 15813 & 10 \\
\hline 3 & Emewe & 8406 & 6 \\
\hline 4 & Odu I & 7271 & 5 \\
\hline 5 & Odu II & 10358 & 6 \\
\hline 6 & Abocho & 22427 & 13 \\
\hline 7 & Ogbabede & 10563 & 6 \\
\hline 8 & AdumuEgume & 15078 & 5 \\
\hline 9 & Ojikpalada & 7868 & 23 \\
\hline 10 & Anyigba & 38008 & 5 \\
\hline 11 & Okura Olafia & 8873 & 5 \\
\hline 12 & OganeInugu & 8911 & 100 \\
\hline & Total & 166,165 & \\
\hline
\end{tabular}

Table 1: Voter Population and Spread 


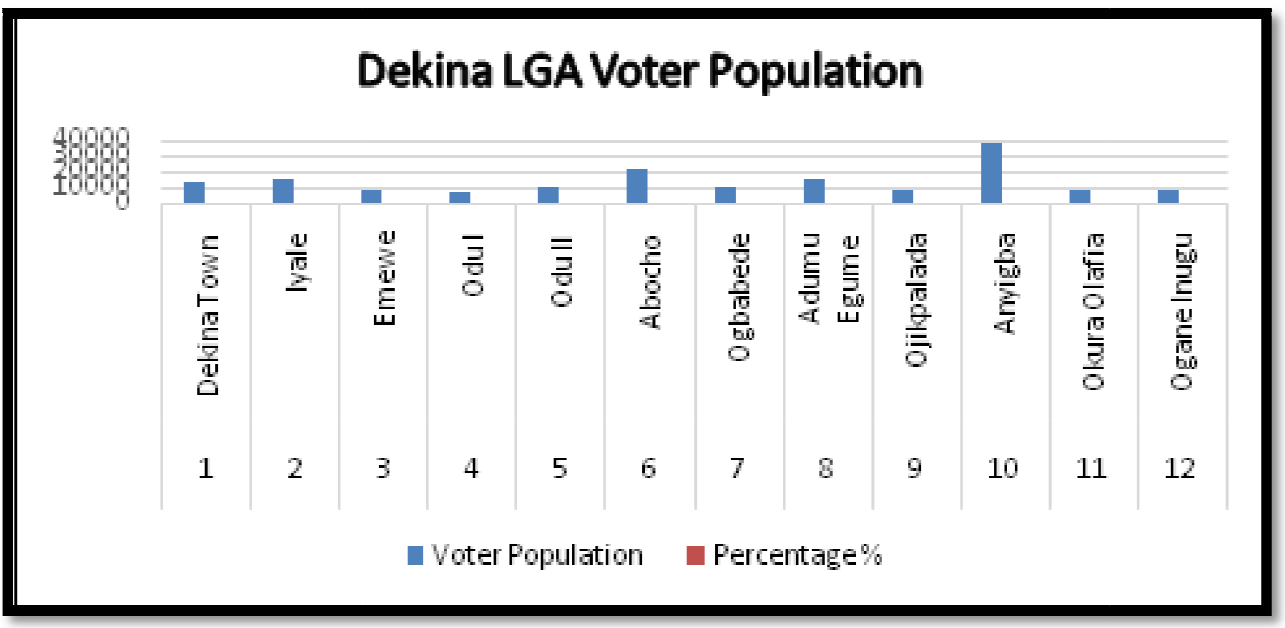

Figure 1: Bars Showing Dekina LGA Voter Population

The result shows that, Dekina LGA population has more registered voters in Anyigba (23\%). The importance of this information/data on voter population and spread is of primary relevance as it relates to providing smart decision platforms to electioneering. It is valuable to politicians as it helps them to be acquainted with the knowledge of where to concentrate and allocate resources during campaigns and advocacies. It is also vital to electoral bodies or officials as it helps them to know where there is need for more voter education, where to deploy more abled personnel's and even in the distribution of election materials as to meet the demand of the voter population.

It is as well invaluable to security bodies as it helps them to know that perpetrators of election crime may concentrate their mischief in areas of high voter population density, thereby deploying more security personnel to such areas to ease the effect of electoral violence.

\subsection{Mapping of Polling Units}

The map of Dekina LGA showing the 12 political wards and the 217 polling units distributed among the 12 wards was produced.

The map produced shows that Ogbabede has the highest distribution with 31 polling units about $14 \%$ of the 217 polling units of Dekina LGA but with a less percentage of voter population followed by Abocho with 29 polling units about $13 \%$ with an average percentage of voter population followed by Anyigba with 27 polling units about 12 percentage but with the highest voter population. Emewe with 19 polling units about 9\%, OganeInigu with 18 polling units about $8 \%$, Iyale with 17 polling units about 8\%, Odu II and Ojikpalada with 11 Polling units about 5\% respectively. Odu, I have the least polling unit i.e., 9 about $4 \%$ of the 217 polling units within Dekina LGA (see Table 2 and figure 4.2.1)

\begin{tabular}{|c|c|c|c|c|c|}
\hline S/N & Wards & $\begin{array}{c}\text { Total } \\
\text { Polling Units }\end{array}$ & $\begin{array}{c}\text { Percentage } \\
\mathbf{\%}\end{array}$ & $\begin{array}{c}\text { Voter } \\
\text { Population }\end{array}$ & $\begin{array}{c}\text { Percentage } \\
\mathbf{\%}\end{array}$ \\
\hline 1 & Dekina Town & 16 & 8 & 12589 & 7 \\
\hline 2 & Iyale & 17 & 8 & 15813 & 10 \\
\hline 3 & Emewe & 19 & 9 & 8406 & 6 \\
\hline 4 & Odu I & 9 & 4 & 7271 & 5 \\
\hline 5 & Odu II & 11 & 5 & 10358 & 6 \\
\hline 6 & Abocho & 29 & 13 & 22427 & 13 \\
\hline 7 & Ogbabede & 31 & 14 & 10563 & 6 \\
\hline 8 & AdumuEgume & 14 & 6 & 15078 & 9 \\
\hline 9 & Ojikpalada & 11 & 5 & 7868 & 5 \\
\hline 10 & Anyigba & 27 & 12 & 38008 & 23 \\
\hline 11 & Okura Olafia & 15 & 8 & 8873 & 5 \\
\hline 12 & OganeInigu & 18 & 8 & 8911 & 5 \\
\hline & Total & 217 & 100 & 166165 & 100 \\
\hline
\end{tabular}

Table 2: Table Showing Polling Units and Voter Population Spread 


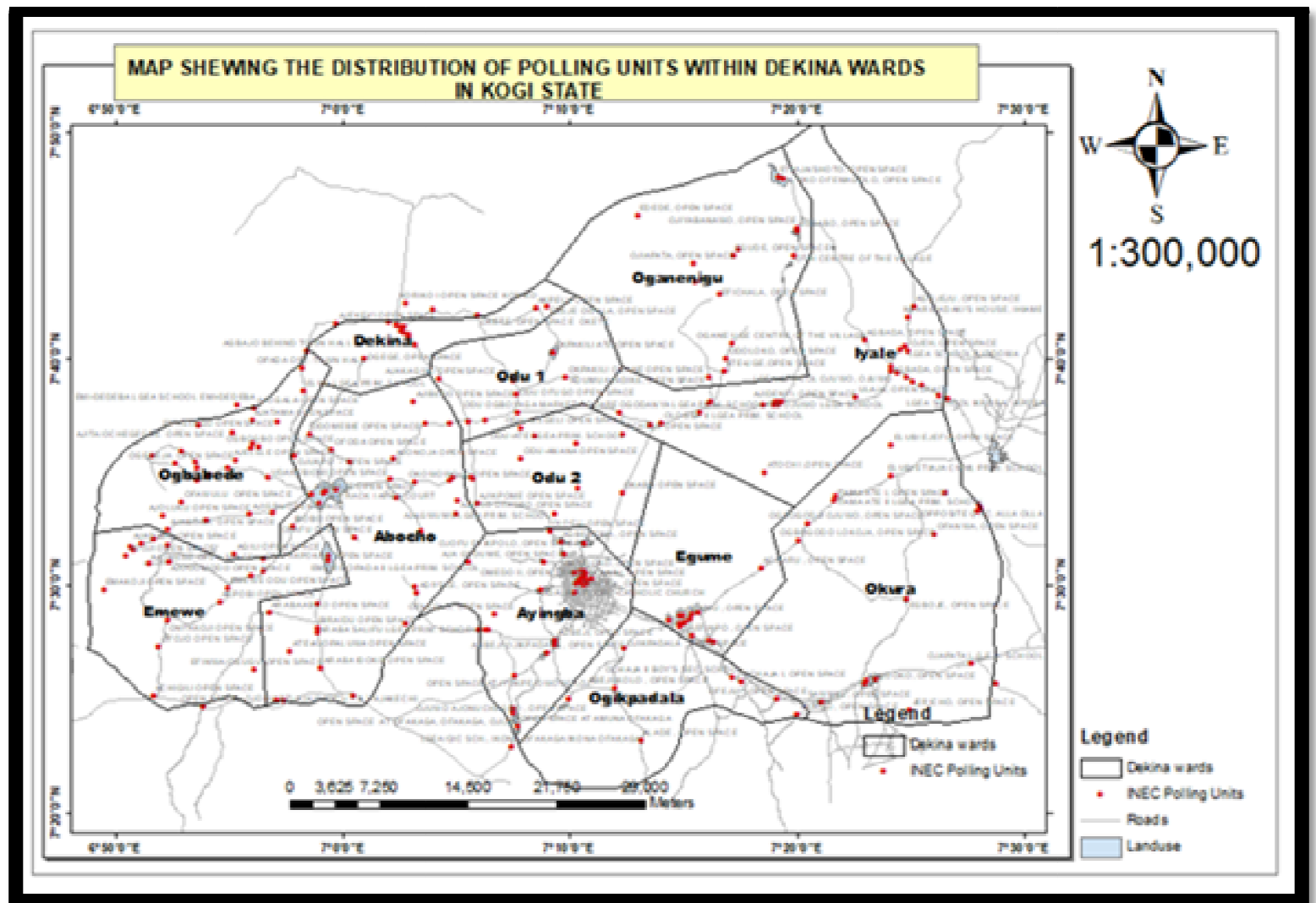

Figure 2: Dekina Polling Units

The result (Figure 2) shows the spatial distribution of Polling Units within the different wards of Dekina LGA. It shows that the polling units are not evenly distributed but are clustered in some areas as seen above (see figure 4.2.1) i.e., Anyigba, Egume, Dekina Town and some part of Iyale. This shows reason why the voter turnout on election day is poor because of the wide distance from little settlements to polling units.

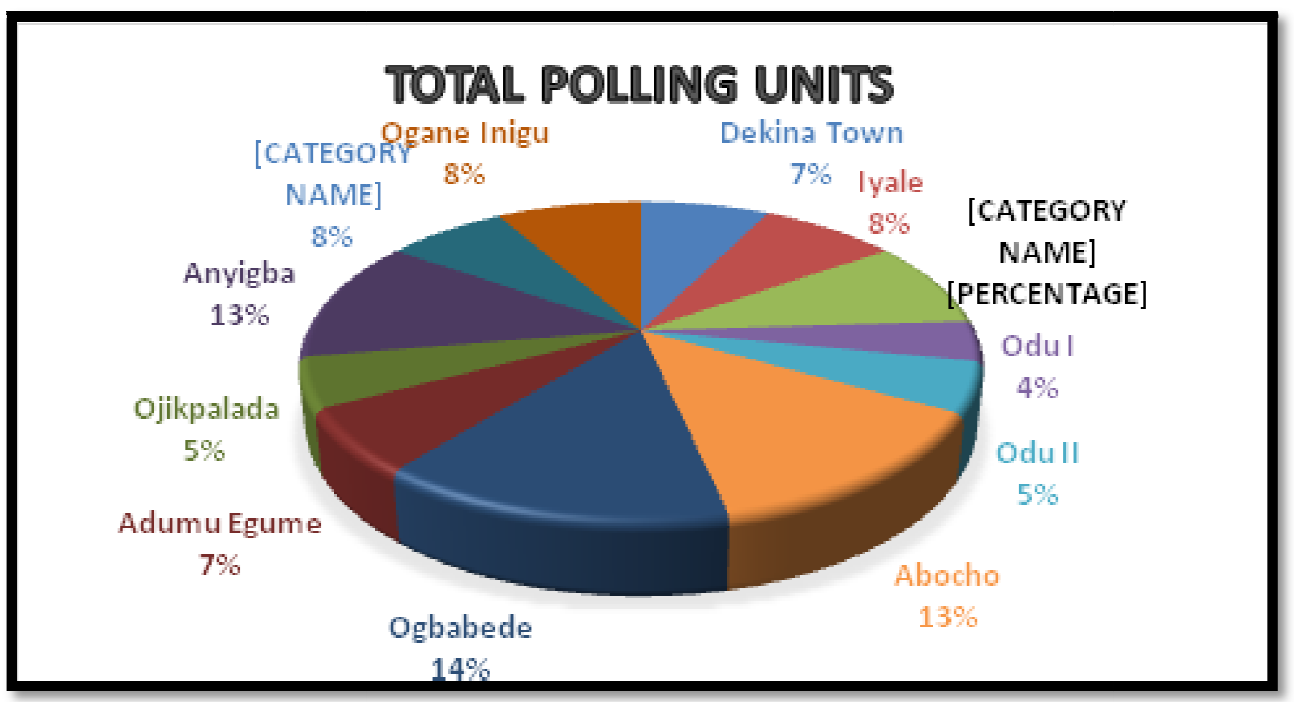

Figure 3: Pie Chart Showing Polling Units Spread

\subsection{Database Query}

A single query Operation conducted to determine all the polling units with over 500 registered voters within dekina LGA as shown in figure 4.3 


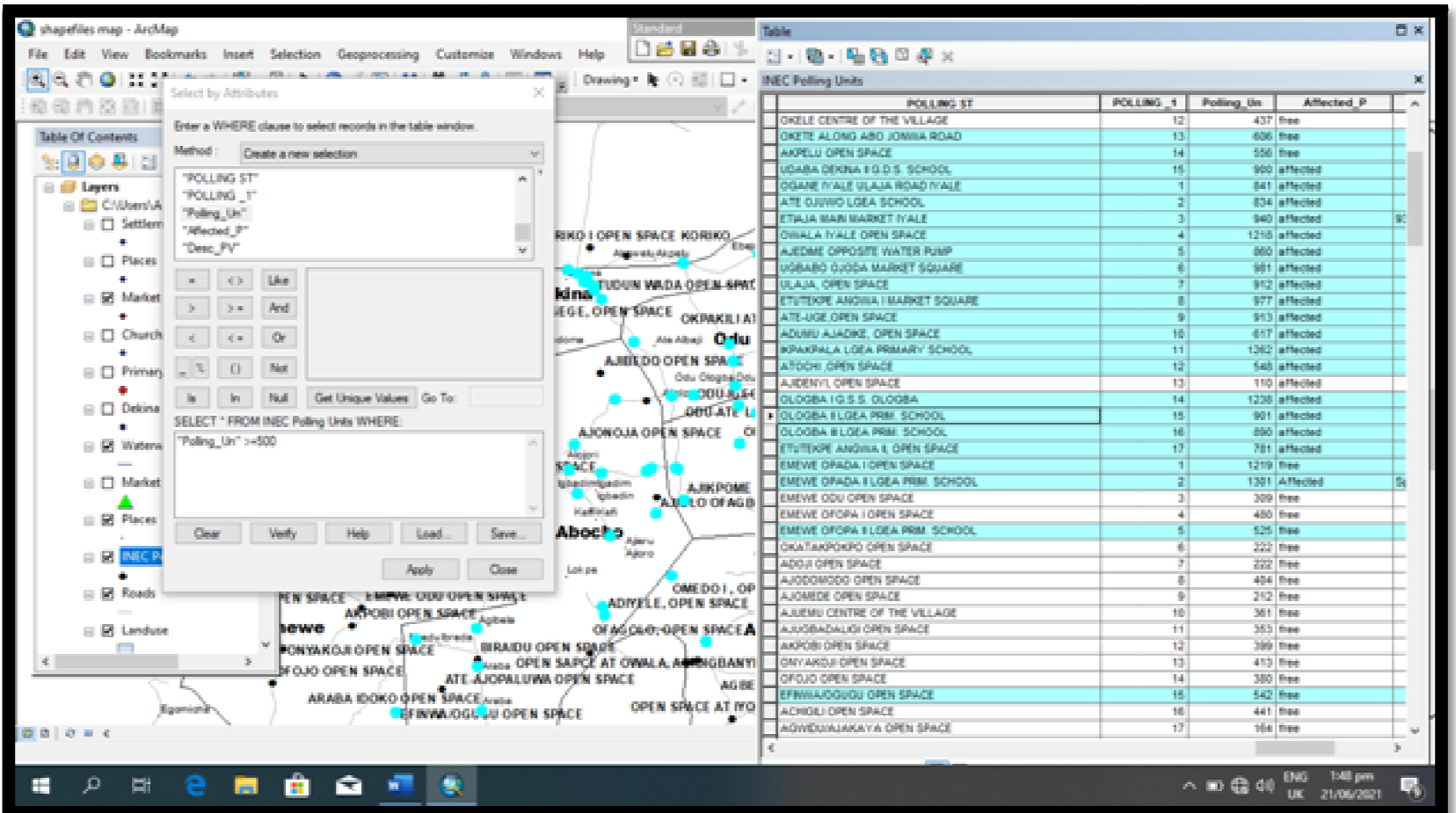

Figure 4: Showing the Query Result of All Polling Units with Over 500 Registered Voters

The Result Showed that 147 polling units out of the total 217 polling has registered voters of above 500 voters. According to Section 22 of the Electoral Act, it says that each polling unit is not supposed to have more than 500 registered voters. This result shows that 147 polling unit out of a total of 217 polling units within the study area violated this law. It shows that there is congestion in 147 polling units within the study area. This result will help the INEC officials to know where to create more polling units to reduce the congestion in the affected polling units.

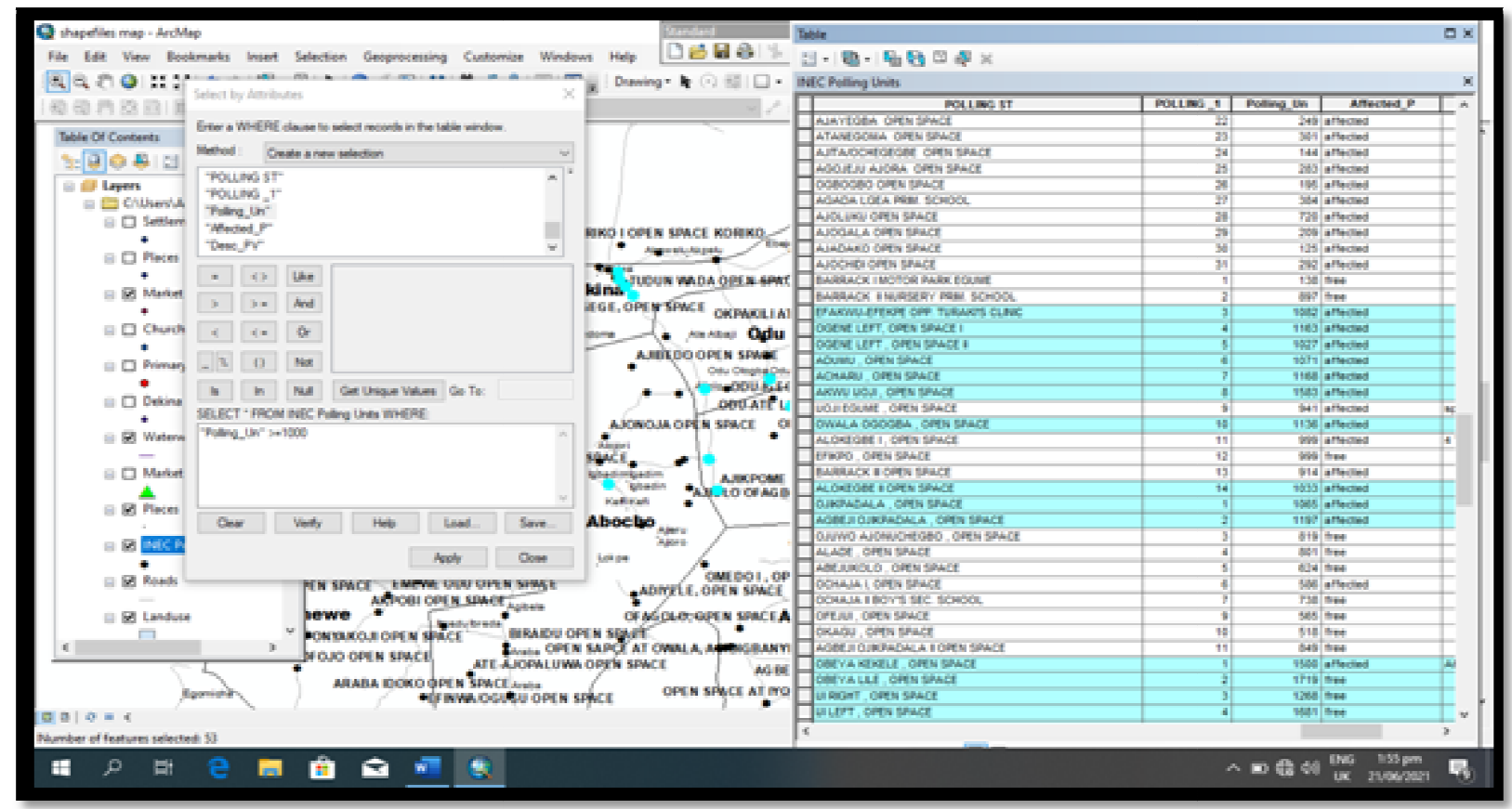

Figure 5: Showing the Query Result of All Polling Units Over 1000 Registered Voters

The result shows that 53 polling units out of a total of 217 polling units within Dekina LGA has a voter population of above 1000 registered voters. 


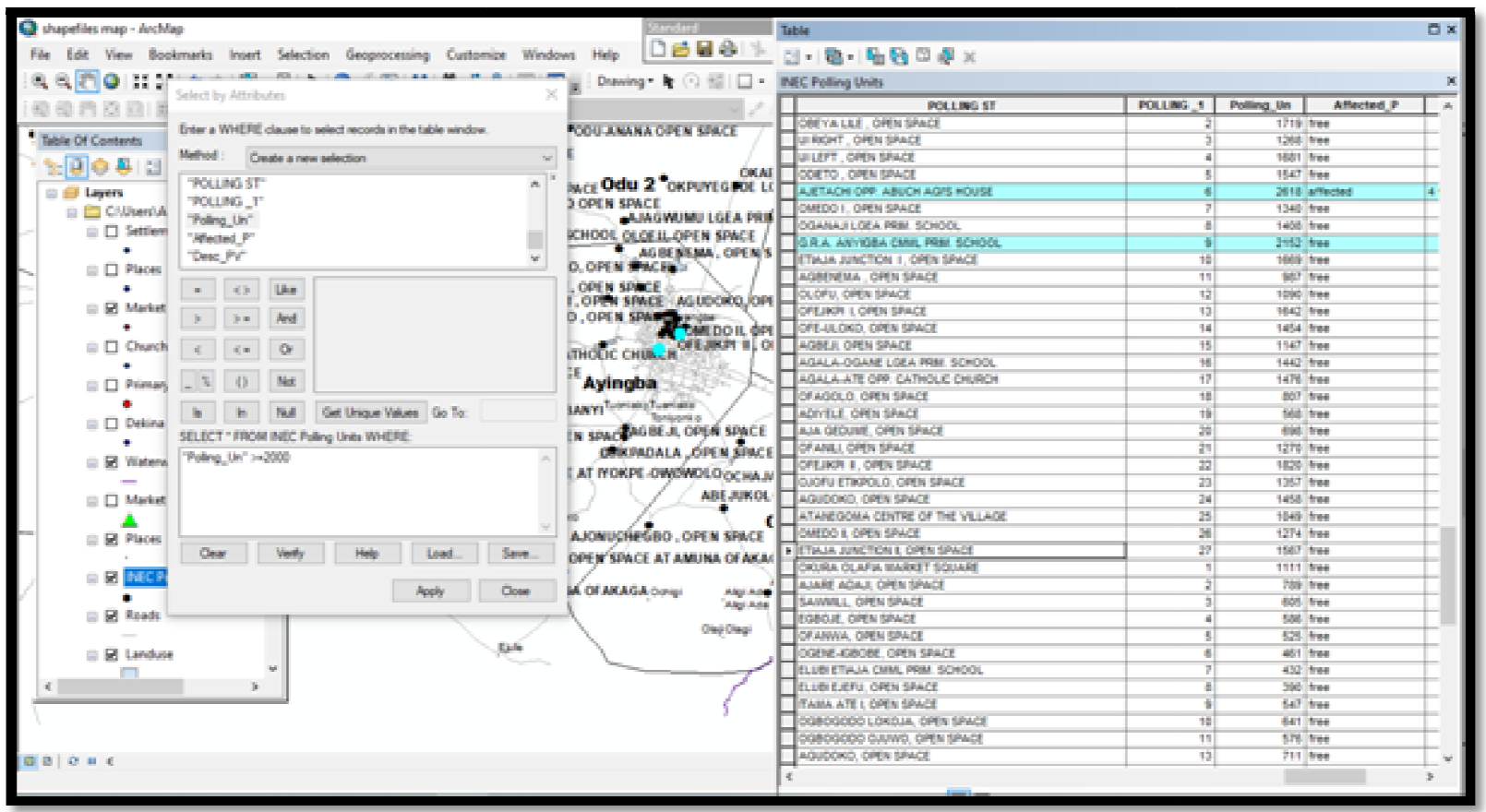

Figure 6: Showing the Polling Units with above 2000 Registered Voters

The result Showed that two (2) polling units out of 217 polling units in Dekina LGA have more than 2000 registered voters. These polling units happens to be in the same ward i.e., Anyigba ward. This result will help the electoral officials to know areas with rapid population growth. Anyigba needs more of polling units as there is a rapid growth of population within the ward. This result will help the electoral officials to know where to deploy more electoral materials and also carry out more of voter sensitization and education for election awareness. It will also help the various parties with adequate campaign plan i.e., knowing where to concentrate their resources during advocacies

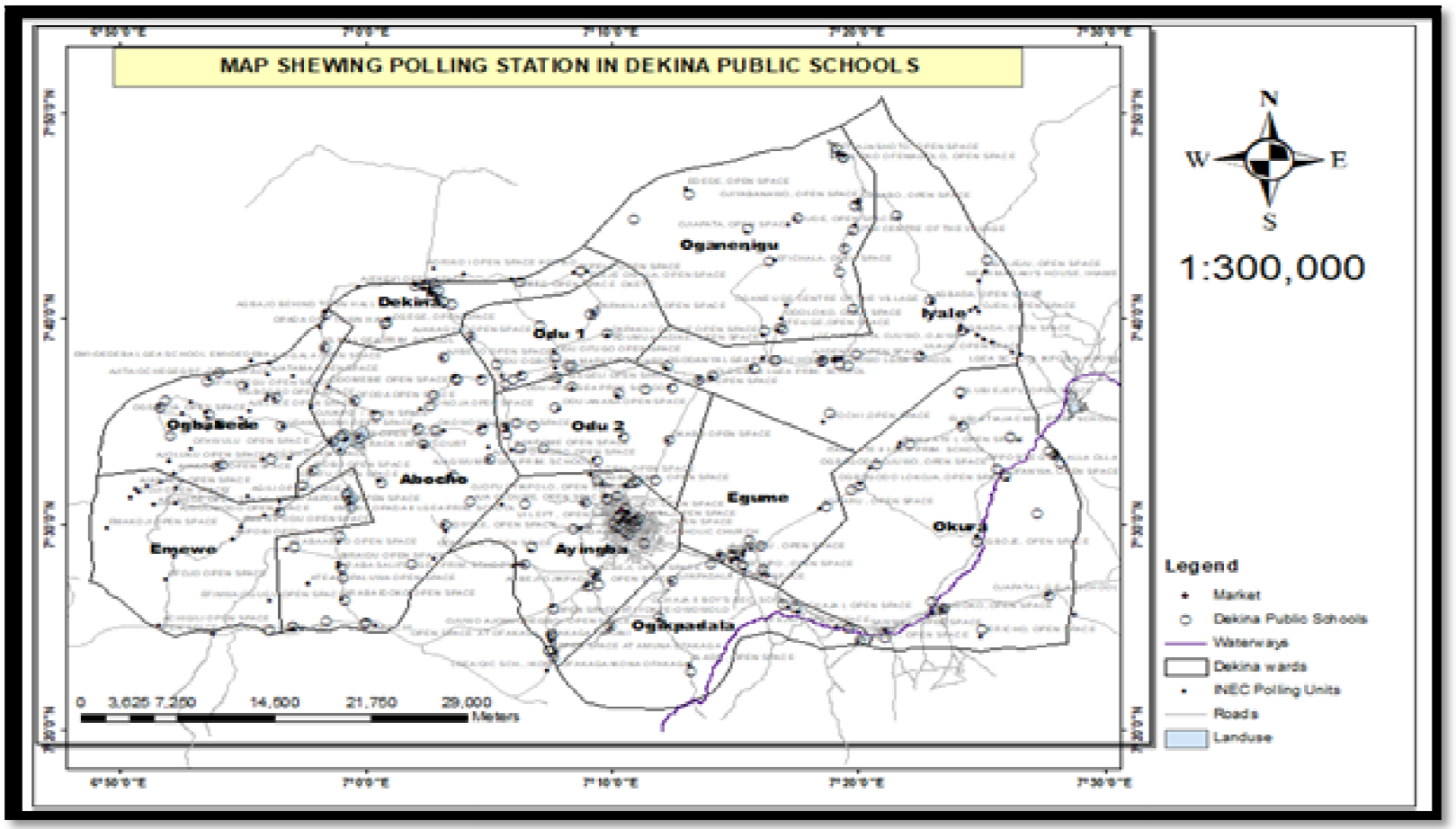

Figure 7: Map Shewing Polling Units Located In Dekina Public School

The result (see figure 4.3.3) shows that 48 of the polling units within Dekina LGA are located in public Schools, 145 in Open Spaces, 10 are located in market square while the rest are in motor packs and Road sides. See figure 4.3.4 for query result. This result will help the electoral officials to know where the polling facilities are located for optimum delivery. Polling units located in public schools with wide open spaces will serve better than polling units located within residence. Location of polling units is vital to a successful poll. Areas with road networks for easy transportation of election materials, areas that are close to settlements to encourage voters. 


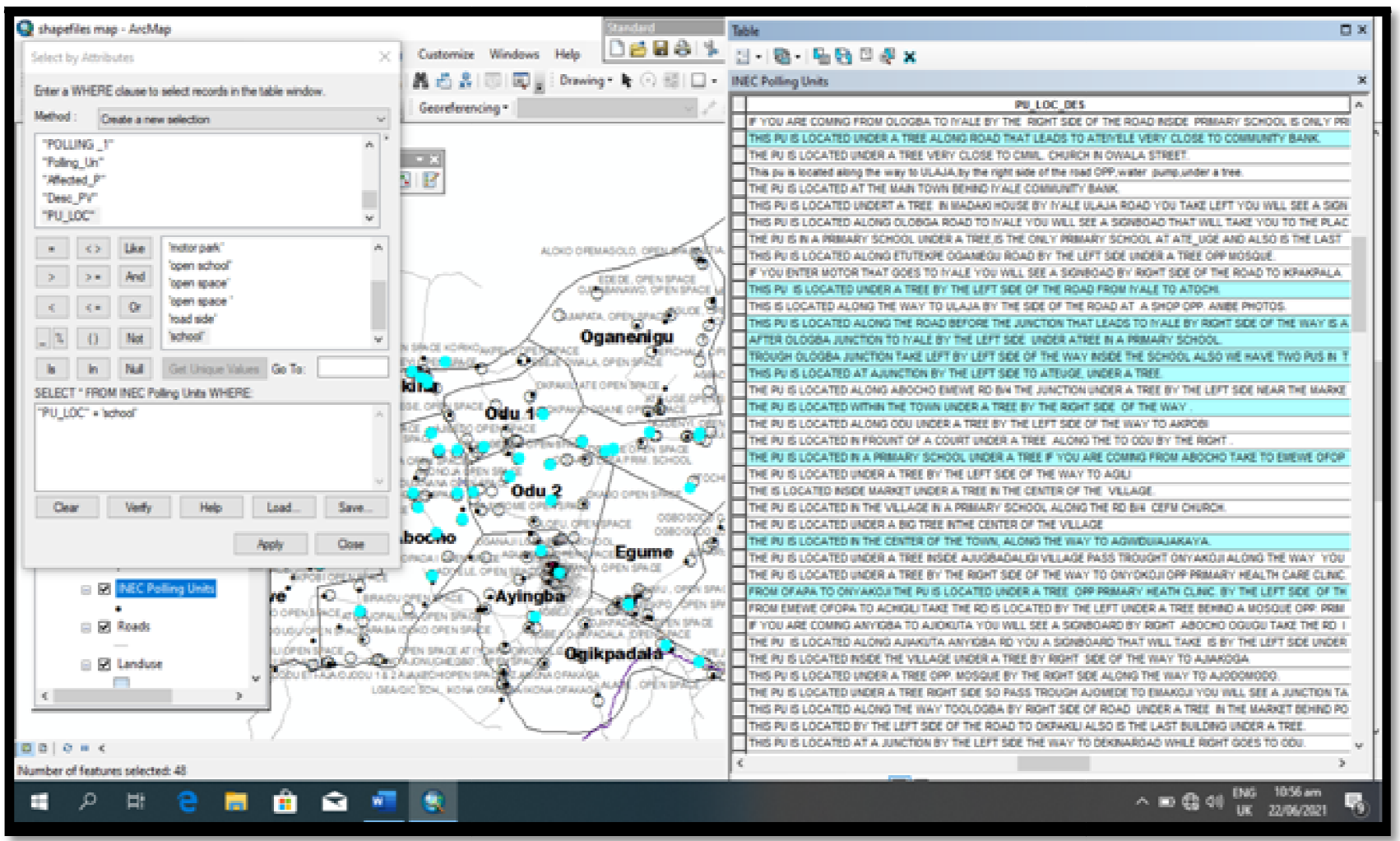

Figure 8: Query Showing Polling Units Located in Schools

\subsection{Mapping Affected Polling Units}

In the last election conducted i.e., 2019 presidential/House of Assemblies election, they were reported incidence of election violence which led to the cancellation of election results in some polling units within Dekina LGA. Knowing the spatial depiction of this polling units along with the number of affected register voters and the kind of violence will help for smart decisions in subsequent elections.

\begin{tabular}{|c|c|c|c|}
\hline S/N & Wards & No of Polling Units Affected & $\begin{array}{c}\text { Percentage } \\
\mathbf{\%}\end{array}$ \\
\hline 1 & Dekina Town & 7 & 9 \\
\hline 2 & Iyale & 17 & 21 \\
\hline 3 & Odu I & 1 & 1 \\
\hline 4 & Odu II & 4 & 5 \\
\hline 5 & Abocho & 2 & 2 \\
\hline 6 & Ogbabede & 31 & 13 \\
\hline 7 & AdumuEgume & 10 & 8 \\
\hline 8 & Ojikpalada & 6 & 1 \\
\hline 9 & Anyigba & 1 & 1 \\
\hline 10 & OganeInigu & 1 & 100 \\
\hline & Total & 80 & \\
\hline
\end{tabular}

Table 3: Numberof Polling Units Affected with Their Percentage 


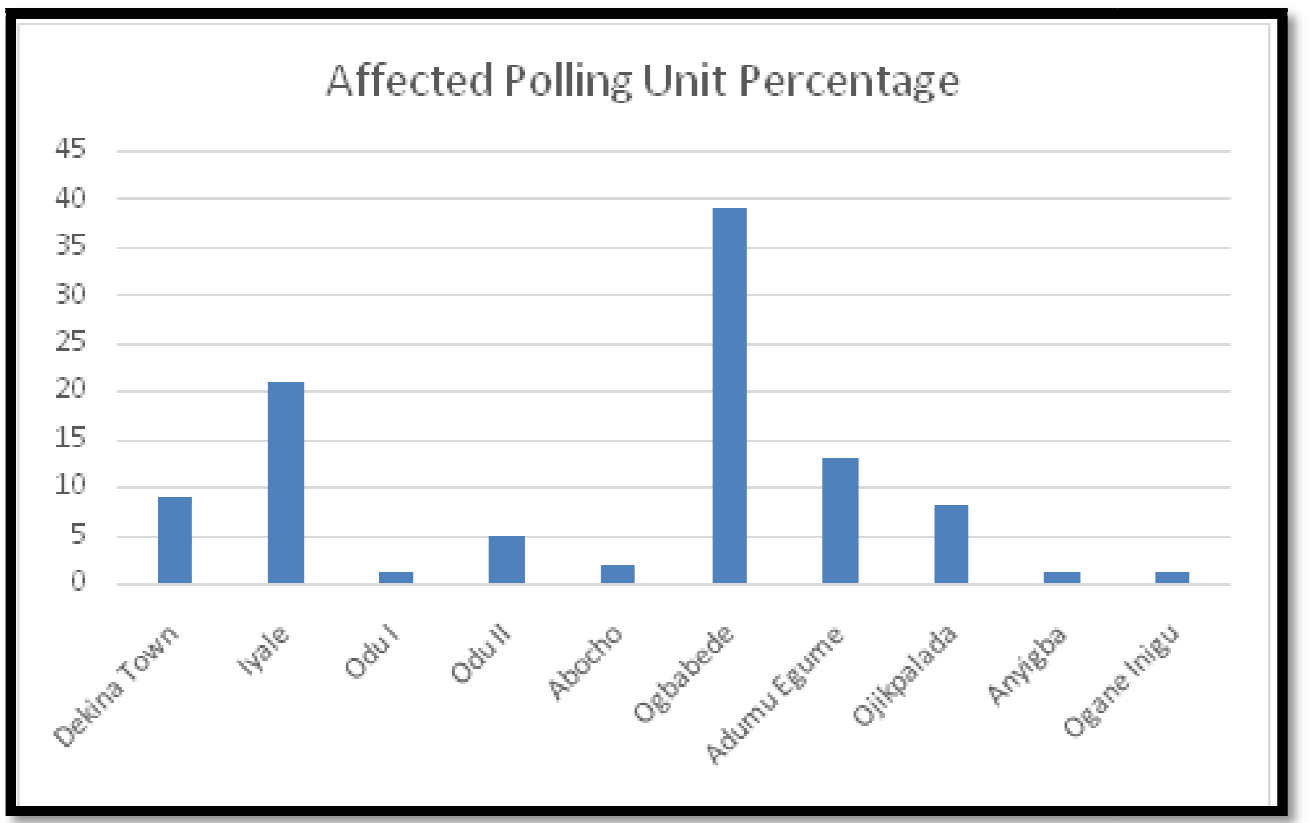

Figure 9: Affected Polling Unit Percentage

The chart (Figure 9) shows that Ogbabede has the highest number of affected polling units followed by Iyale, and then by AdumuEgume, followed by Dekina town and then Ojikpalada, Odu II, Odu I, Anyigba and OganeInigu respectively. This information can be useful for the electoral bodies and officials to know where to place high monitors to avert the incidence of violence that may lead to the cancellation of election results in these areas.

\begin{tabular}{|c|c|c|c|}
\hline S/N & Wards & Registered Voters & Percentage \% \\
\hline 1 & Dekina town & 5527 & 10 \\
\hline 2 & Iyale & 15813 & 28 \\
\hline 3 & Odu I & 745 & 1 \\
\hline 4 & Odu II & 3582 & 6 \\
\hline 5 & Abocho & 1522 & 3 \\
\hline 6 & Ogbabede & 10583 & 19 \\
\hline 7 & AdumuEgume & 11049 & 20 \\
\hline 8 & Ojikpalada & 4132 & 7 \\
\hline 9 & Anyigba & 2618 & 4 \\
\hline 10 & OganeInigu & 870 & 2 \\
\hline Total & & 56441 & 100 \\
\hline
\end{tabular}

Table 4: Number of Registered Voters in the Affected Polling Units and Percentage

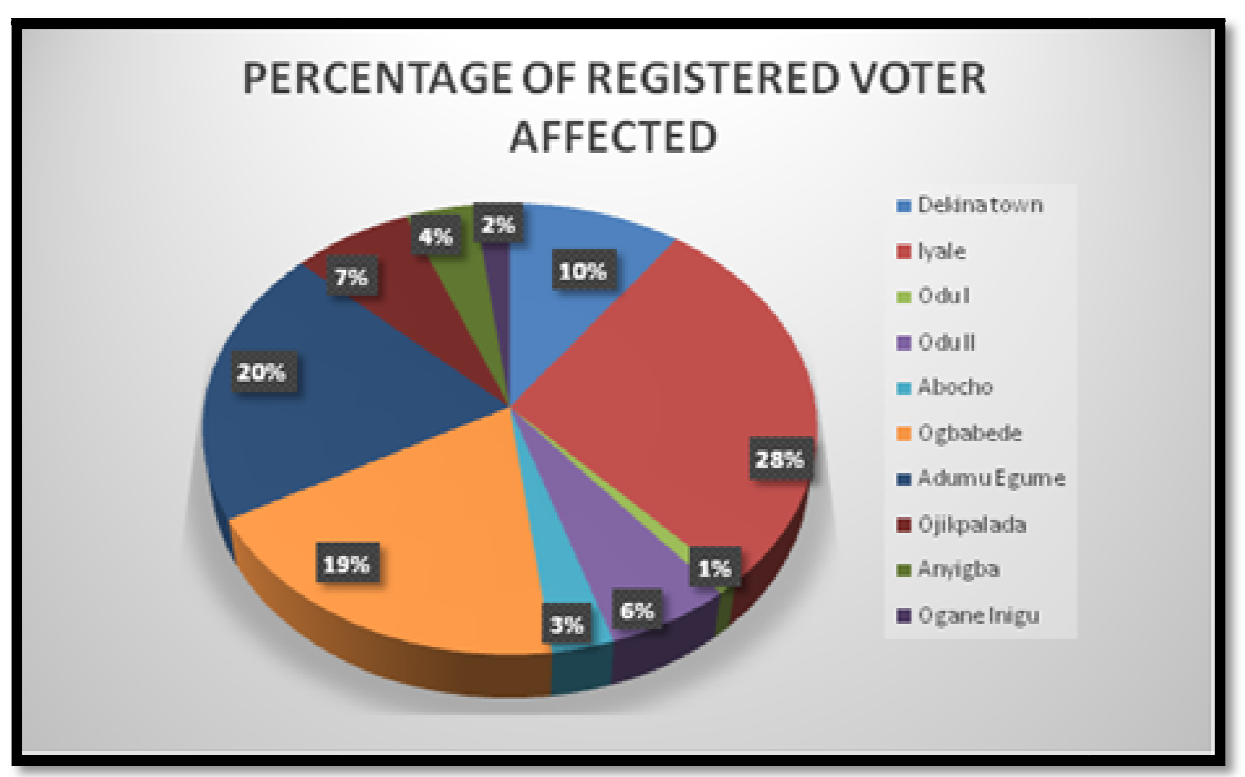

Figure 10: Pie chart of Registered Voter Affected 
Th chart (Figure 10) shows that Iyale has the highest percentage of affected registered voter with $20 \%$ of the total affected voters about 15813 followed by AdumeAgume with AdumuEgume with 20\% about 11049 affected, then Ogbabede with 19\% about 10583 Registered Voter, Dekina town with 10\% about 5527 and then the rest wards with little percentage as shown on the chart (see figure 4.4.2)

\subsection{Database Query for Affected Polling Units}

A single query operation was conducted to display graphically the various affected polling units within the total of 217 polling units within Dekina LGA in the 2019 presidential/ House of Assemblies election. (see figure 4.5).

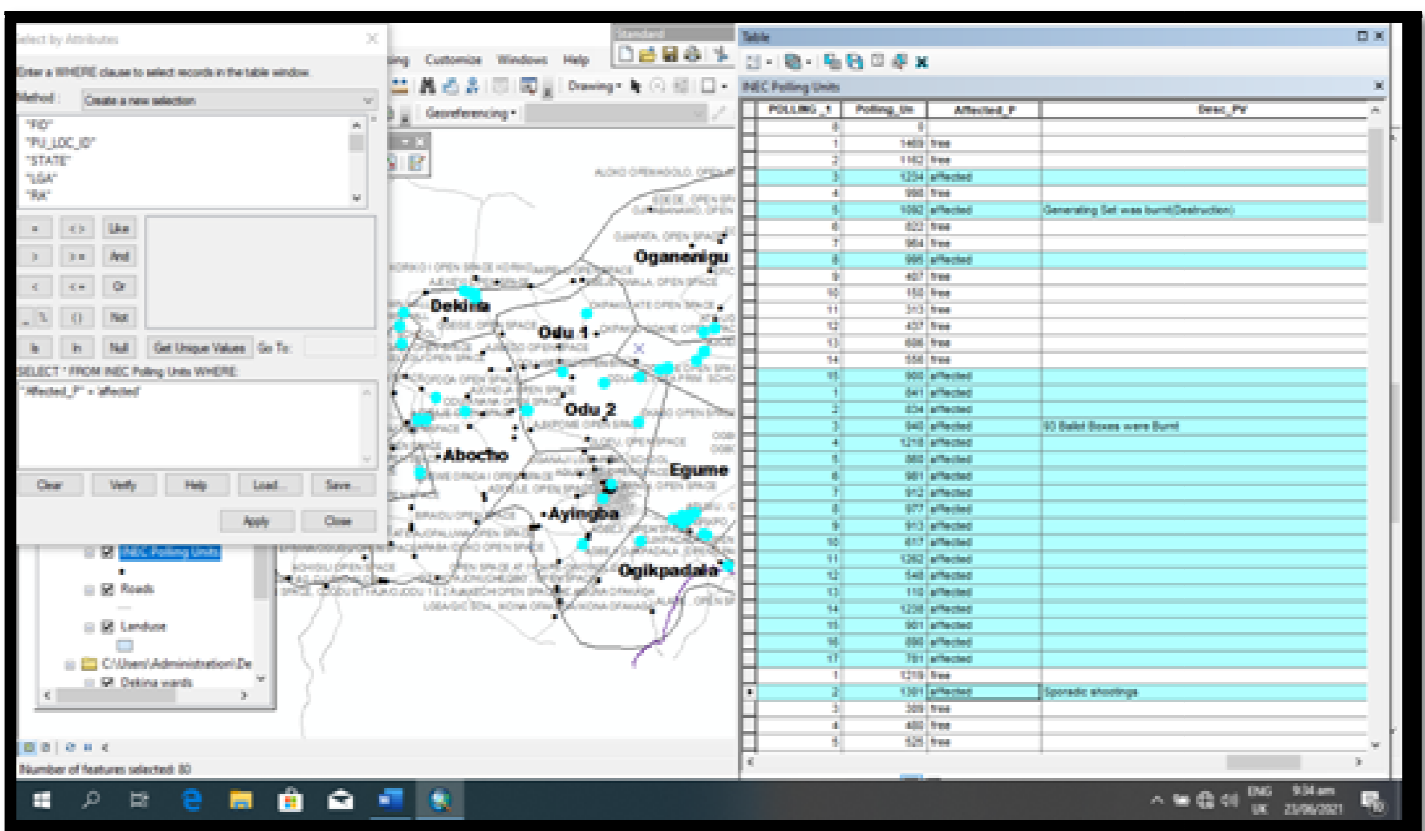

Figure 11: Query Showing Affected Polling Units in Dekinaat 2019 Presidential/House Assemblies

The result (Figure 11) shows that 80 polling units were had violence issues out of a total of 217 polling units. The nature of violence that took place in this polling units that led to the cancellation of election results in this polling units were gunshot, thuggery, intimidation, harassment, kidnapping, destruction of election materials, forceful denial of some personnel to go their polling unit of posting etc. This information will help the election officials to know where to place high monitors in the subsequent election thereby re-enforcing security measures.

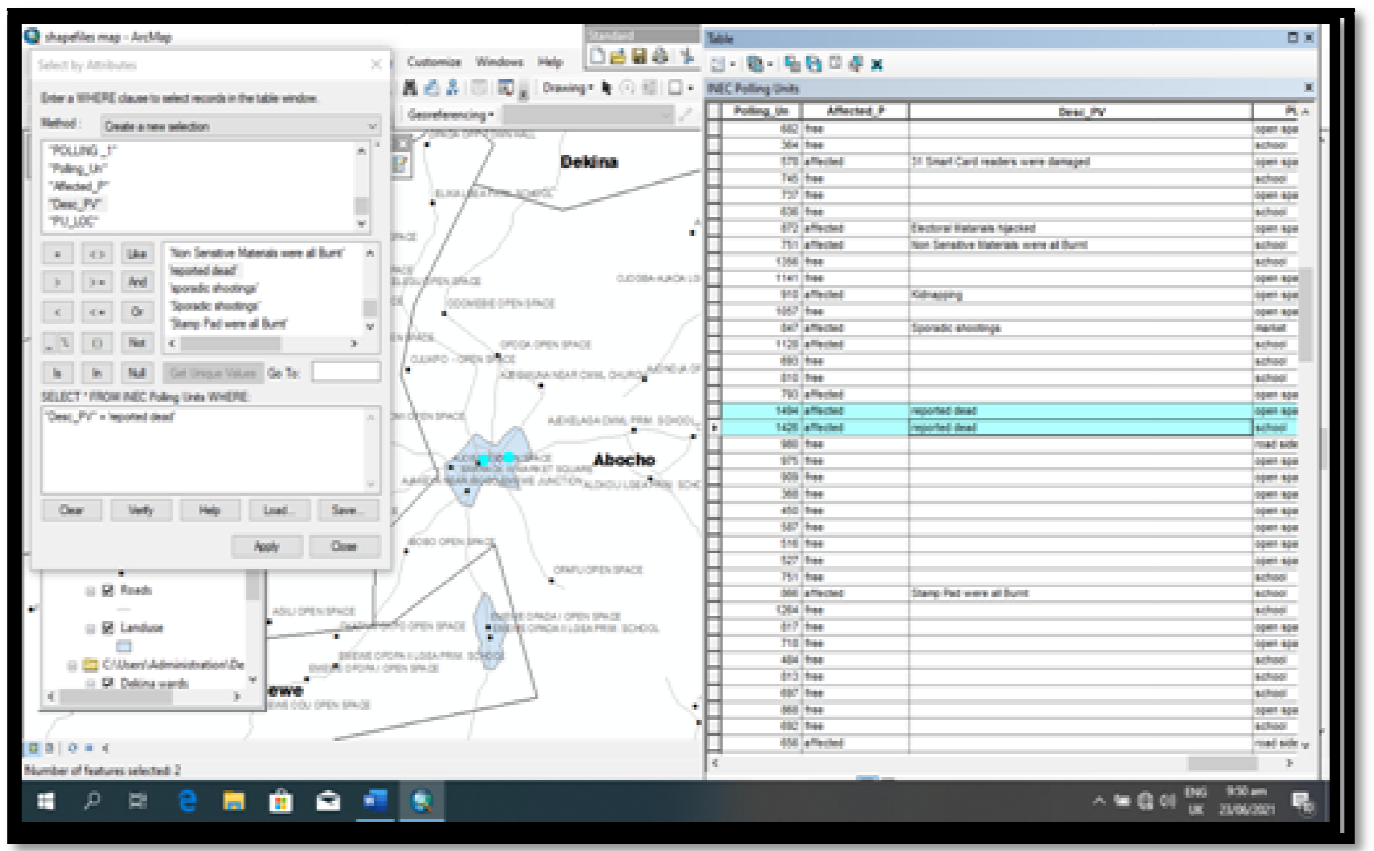

Figure 12: Query Showing Result for Polling Units with Death Record

A query was conducted to show polling units with death record in the last Presidential/ House of Assemblies election. The result shows that, two polling units namely Barrack I area court and Barrack II LGEA primary school witnessed a death record (see Figure 12) 


\section{Summary and Conclusion}

The research has demonstrated successfully the application of Geographic Information System Approach to election Assessment in Dekina Local Government Area of Kogi State, Nigeria.

The following findings were obtained from the study

- The spatial depiction of polling units helps to know the distribution pattern of polling units within the different wards. It shows that some polling units are clustered and some are scarcely distributed. This can result to lesser number of people coming out to carry out their franchise based on the distance of the polling units from their places of residence. It was discovered that they are no polling units around Ochigi, Olaji within Ojikpalada ward of Dekina LGA.

- Anyigba ward has a population of 189,976 as at 2013 (Ifetimehin, 2013), the total number of registered voter in Anyigba in the 2019 Presidential/House of Assemblies was 38,008 which is just 20\% of the population. This suggests why there is a need for more voter sensitization and education in Anyigba Ward. This serves to attest to the fact that, GIS based electoral system enhance geographic visualization of electoral dynamics and electoral demography (Ojiakoet al, 2016)

- The ability of GIS database to store, analyze, and efficiently update electoral data will be of great relevance to electoral officials to be able to conduct, manage and monitor elections. GIS based electoral system provides the platform to effectively and statistically analyze the distribution of voters allocated to each polling unit.

- Depicting Polling Units with records of electoral violence will help the security personnel to know where to take high security measures in order to enhance electoral security.

- GIS based approach to electioneering will improve smart decisions as to where more polling units should be introduced, where is known for electoral violence, where voter education and sensitization should be carried out.

\section{References}

i. Batty, M., Xie, Y., and Sun, Z. L. (1999):Modelling Urban Dynamics Through GIS basedCellular Automata, Computers, Environment and Urban Systems, Vol. 23, 205-233.

ii. Hernandez, M. (2012): 'Database Design for Mere Mortals: A Hands- on Guide To Rotational Database Design.' 3 ${ }^{\text {rd }}$ Edition. Pearson Education, Indianapolis, Indiana. Pp15, 22 and 31.Available at http://en.wikipedia.org/wiki/Relational_database_management_system. Accessed 15th July, 2014.

iii. Idris, A., (2019): Anyigba My Hometown, A brief history of Anyigba. Available Online https://m.facebook.com. Accessed 22 ${ }^{\text {nd }}$ June, 2021

iv. Ifatimehin, 0.0, Falola, and E.v. Odogbo (2013): An analysis of the spatial distribution of plasmodium sporozites and effects of climatic correlates on malaria infection in Anyigba Town, Nigeria. Global Journal of Health Science. Canadian Centre of Science and Education, 3.45

v. Kufoniyi, O. (1998): Database Design and Creation in Ezeigbo, C.U (ed). Principle and Applications of Geographic Information System, Department of Surveying, University of Lagos, pp 62-63.

vi. Spencer, C. (2001):GIS And Crime Mapping. Director Of Geographic Information, UCL JILL, DandoInstitute of Crime Science.

vii. Longley, P. (2001): Geographic Information System And Science.

viii. Nwanegbo, Jaja C. (2015): Electoral process and micro level Rigging in 2015 General elections in Anambra West and Awka North Local government area of Anambra State, Paper submitted to the two-day National conference on -the 2015 General elections in Nigeria; The real issues, June 17-18, 2015 by the electoral institute (TEI), of the independent National Electoral Commission (INEC).

ix. Ojiako J.C., Fashina O.P., Igbokwe E.C, Enedah, I.C (2016): Geographic Information System based Approach to preElection Monitoring in Awka South Local Government Area of Anambra State, Nigeria, International Journal of advanced Engineering, Management and Science, vol 2 pp 1466-1269

x. Omoleke Muslim Esq and Maduekwe, Nnamdilfeanyi (2017): The use of geospatial Technology for mapping Elections in Nigeria: Issues and Challenges, International journal of innovation and research in educational sciences. Vol 4, pp. 509-512

xi. Waldemar W. (2013): Functions of Election in Democratic Systems, Political Preferences, No 4/2013 